Захарова Н. В.

ИССЛЕДОВАНИЕ СТЕРЖНЕВЫХ СМЕСЕЙ НА ОСНОВЕ ПОЛИМЕРНЫХ СВЯЗУЮЩИХ

Захарова Н. В.

N. V. Zakharova

ИССЛЕДОВАНИЕ СТЕРЖНЕВЫХ СМЕСЕЙ НА ОСНОВЕ ПОЛИМЕРНЫХ СВЯЗУЮЩИХ

\title{
THE STUDY OF CORE SAND MIXTURES BASED ON POLYMERIC BINDERS
}

Захарова Наталья Владимировна - кандидат технических наук, доцент кафедры теории и методики технологического образования Амурского гуманитарно-педагогического государственного университета (Россия, Комсомольск-на-Амуре); 8(4217)52-12-05.

Ms. Natalia V. Zakharova - $\mathrm{PhD}$ in Engineering, Associate Professor, Theories and Principles of Engineering Education Department, Amur State University of Humanities and Pedagogy (Russia, Komsomolsk-on-Amur); 8(4217)52-12-05.

Аннотация. Рассмотрена возможность применения отходов пенополистирола в качестве самостоятельного связующего при изготовлении стержневых смесей. Представлены экспериментальные данные, полученные при исследовании свойств стержневых смесей в зависимости от способа и порядка ввода, количества раствора пенополистирола, его вязкости и способа сушки. Рассмотрена возможность использования раствора пенополистирола в качестве самостоятельного связующего и в качестве полимерной добавки.

Summary. The possibility of using foamed polystyrene waste as the binder in manufacturing core sand mixtures. The article provides experimental data obtained by studying the core sand mixtures properties depending on the methods of addition, foamed polystyrene solution amount, its viscosity and the method of drying. The author investigates the ways of using foamed polystyrene as the binder and as the polymeric additive.

Ключевые слова: стержневые смеси, раствор, пенополистирол, отливка, связующее, жидкое стекло, лигносульфонат.

Key words: core sand mixture, solution, foamed polystyrene, cast molding, binder, liquid silica, lignosulfonate.

УДК 621.742 .48

При изготовлении отливок наиболее распространёнными являются технологии разовых песчаных форм.

Получение чистых внутренних полостей отливок, формуемых стержнями, затруднено последующими трудоёмкими операциями по повышению чистоты поверхности.

Стержневые смеси должны обладать достаточными технологическими свойствами, чтобы избежать разрушения при постановке в форму и заливке металла.

Поэтому при изготовлении стержневых смесей для повышения прочностных свойств, термической стойкости, улучшения выбиваемости, снижения прилипаемости применяют различные сочетания органических и неорганических связующих.

В данной работе представлены результаты исследования возможности применения углеродосодержащей добавки в качестве самостоятельного связующего при изготовлении жидкостекольных стержневых смесей и смесей на основе лигносульфоната.

В качестве такой добавки принимался раствор пенополистирола в толуоле. Исходя из анализа теоретических и практического данных в исследуемой стержневой смеси исполь-

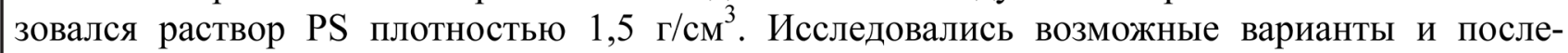


довательность ввода компонентов смеси для получения состава с улучшенными прочностными свойствами.

Лигносульфонат является связующим тёплового отверждения. Он не получил широкого распространения как самостоятельное связующее, т.к. он не обеспечивает достаточной прочности стержней в отверждённом состоянии. Для улучшения связующих свойств лигносульфонат совмещают с другими связующими или органическими соединениями.

Жидкое стекло в литейном производстве - одно из самых распространённых неорганических связующих. Как литейное связующее применяется при СО 2 -процессе изготовления стержней и форм, используется в составах самотвердеющих смесей, отверждение которых происходило при комнатной температуре под влиянием вводимых в смесь отвердителей. Основным недостатком в процессе производства отливок с использованием жидкостекольных стержневых смесей является образование пригара на поверхности отливок и внутри оформляемых полостей и низкая выбиваемость.

Одним из наиболее эффективных способов улучшения выбиваемости жидкостекольных смесей является уменьшение доли жидкого стекла в смеси. Уменьшение содержания жидкого стекла не должно повлечь за собой снижения начальной прочности смеси и ухудшения её физико-механических и технологических свойств.

Также улучшить свойства смесей на основе жидкого стекла и лигносульфоната можно введением углеродосодержащих добавок. При термодеструкции формовочных смесей с углеродосодержащими добавками происходит выделение пироуглерода. Раствор пенополистирола обеспечивает наибольший (более 50 \%) выход пироуглерода, что даёт возможность использования раствора как самостоятельного связующего, а также как полимерную добавку для упрочнения смеси с лигносульфонатом и для разупрочнения стержней после отверждения (жидкостекольные смеси).

Улучшение адгезионных свойств плёнкообразующих веществ за счёт введения их в толуол (ароматический углеводород) обосновывает выбор раствора пенополистирола в качестве связующего.

При введении раствора пенополистирола различной концентрации в жидкое стекло или лигносульфонат прочность стержней после отверждения увеличивается в 2...3 раза.

Уменьшить остаточную прочность стержневых смесей на основе жидкого стекла для $\mathrm{CO}_{2}$-процесса в $10 \ldots 15$ раз можно при плакированнии наполнителя раствором пенополистирола [7]. При содержании в смеси 3...4\% раствора пенополистирола 20...40\%-ной концентрации предел прочности после сушки стержня находится в пределах 1,7...2,0 МПа, после $\mathrm{CO}_{2}$-процесса - 0,7..1,2 МПа. Остаточная прочность варьировалась в пределах $0,009 \ldots 0,02 \mathrm{MПа} \mathrm{[3].}$

При использовании раствора пенополистирола как самостоятельного связующего прочность стержневой смеси после отверждения достигает 3..3,5 МПа. Это достигается введением в наполнитель $4 . .5 \%$ раствора пенополистирола $30 . .40 \%$-ной концентрации. Кроме того, смесь имеет нулевую адгезию к оснастке, появляется возможность приготовления литейных стержней без противопригарного покрытия.

Прочностные свойства смеси повышает и непосредственное введение 2 ...3 \% раствора пенополистирола 15...30\%-ной концентрации в жидкое стекло (2...3 \%). Предел прочности стержней после сушки составляет 2..2,5 МПа, после $\mathrm{CO}_{2}$-процесса - 0,2 ...0,4 МПа. Начальное и остаточное временное сопротивление смеси на разрыв зависит от метода отвердения, очерёдности и метода ввода, пропорций составляющих связующего, температурного режима и временного интервала отвердения стержневой смеси. При вводе в жидкое стекло $(1 \ldots 2 \%) 2 \ldots 3 \%$ раствора пенополистирола $15 \ldots 30 \%$-ной концентрации предел прочности литейных стержней после сушки находится в пределах 2..2,5 МПа, после $\mathrm{CO}_{2}$-Процесса - в пределах 0,20...0,40 МПа. Остаточная прочность стержней составляет 0,01 ..0,03 МПа. 
Захарова Н. В.

ИССЛЕДОВАНИЕ СТЕРЖНЕВЫХ СМЕСЕЙ НА ОСНОВЕ ПОЛИМЕРНЫХ СВЯЗУЮЩИХ

Плакирование наполнителя $3 \ldots 4 \%$ раствором пенополистерола $20 \ldots 40 \%$-ной концентрации повышает временное сопротивление на разрыв при воздействии температуры в пределах $1,70 \ldots 2$ МПа, после $\mathrm{CO}_{2}$-процесса - 0,7...1,2 МПа. Остаточная прочность смесей $0,01 \ldots 0,04$ МПа.

Способ ввода раствора пенополистирола в смесь на основе жидкого стекла, отверждённую по $\mathrm{CO}_{2}$-процессу, влияет на коэффициент разупрочнения. При плакировании наполнителя раствором пенополистирола и последующим вводом жидкого стекла у образцов отмечается максимальный коэффициент разупрочнения, чем при вводе раствора пенополистирола непосредственно в жидкое стекло. Это можно объяснить тем, что раствор пенополистирола обволакивает зёрна наполнителя (находясь под силикатной плёнкой) и при низких температурах прогрева стержней способствует прорыву силикатной плёнки, в результате чего трудоёмкие операции по выбивке стержней снижаются. При температурах $t>800^{\circ} \mathrm{C}$ в условиях недостатка кислорода возможно частичное выгорание добавки, что ведёт к образованию инертной прослойки сажистого углерода.

Инертная прослойка, в свою очередь, снижает адгезию плёнок и уменьшает прочность смесей. Поэтому введение раствора пенополистирола увеличивает коэффициент разупрочнения $K_{\mathrm{p}}$.

Введение раствора пенополистирола в наполнитель оказывает положительное влияние на предел прочности в сухом состоянии (более $2 \mathrm{MПа),} \mathrm{снижает} \mathrm{содержание} \mathrm{в} \mathrm{смеси} \mathrm{жидкого}$ стекла в 1,5...2 раза. Благодаря уменьшению толщины плёнки жидкого стекла улучшается выбиваемость смеси из отливок. Разупрочнение стержня после заливки металла в форму происходит за счёт термодеструкции вводимого в смесь раствора пенополистирола.

Полученная смесь отличается пониженной адгезией к оснастке, возможностью автоматического смесеприготовления и повторного использования смеси, стабильностью размеров стержней и форм при заливке, получением чистой поверхности отливки без использования противопригарного покрытия.

При приготовлении стержневой смеси на основе лигносульфоната с заданными свойствами определяющим фактором является объём включаемых компонентов связующего [6].

Производство стержневой смеси с лигносульфонатным связующим после отверждения под воздействием температуры, с нулевой адгезией к оснастке, пониженной гигроскопичностью и возможностью использования стержня без противопригарного покрытия возможно при добавлении $1 . .3 \%$ раствора пенополистирола и $1 \ldots 2 \%$ лигносульфоната. Временное сопротивление на разрыв такой смеси составляет 1,8...2,2 МПа.

Из вышесказанного можно сделать вывод, что при введении раствора пенополистирола в состав стержневой смеси на основе лигносульфоната повышается термостойкость и улучшаются технологические и физико-механические свойства стержневой смеси. Также повышаются качество стержней и предел прочности на разрыв в «сыром» состоянии и после сушки, адгезия к оснастке сводится к нулю. Обеспечивается качественная поверхность отливки без применения противопригарной краски. Опытным путём установлено, что для смесей на основе лигносульфоната с добавкой раствора пенополистирола рекомендуемая температура сушки стержней $t=200 \ldots 225^{\circ} \mathrm{C}$. Дальнейшее повышение температуры приводит к понижению прочностных характеристик.

Таким образом, предел прочности на разрыв стержней, изготовленных из смесей на лигносульфонатном связующем, имеет прямую зависимость от пропорций начальных компонентов связующего, температурного режима и времени отверждения. Наибольшая прочность (1,8 МПа) достигается при вводе в смесь до $3 \%$ раствора пенополистирола при температуре сушки не выше $225^{\circ} \mathrm{C}$. Таким образом, ввод в смесь раствора пенополистирола улучшает технологические свойства смеси, сокращает расход лигносульфоната до 1 \% и уменьшает суммарное содержание связующего [4]. 
Исходя из проведённых исследований были получены следующие результаты. Выявлено, что прочностные свойства смесей улучшаются при введении раствора пенополистирола непосредственно в смесь.

Увеличение концентрации раствора пенополистирола более $30 . .40 \%$ ведёт к возрастанию вязкости связующего, раствор загустевает и становится пластичным. При увеличении концентрации более 50 \% раствор переходит в гелеобразное состояние.

При введении в наполнитель $5 . .6 \%$ раствора пенополистирола происходит увеличение прочности $(2,7 \ldots 3,0 \mathrm{MПа)}$. Последующий рост количества и концентрации связующего (более 40 \%) приводит к ухудшению прочностных характеристик смеси.

Максимум «сырой» прочности $(0,6 \ldots 1,2$ МПа) достигается к моменту приобретения связующим пластических свойств, т.е. когда содержание раствора в связующем и смеси достигает критической концентрации [4].

Экспериментальные данные показали, что максимальное разупрочнение стержней происходит при вводе в смесь 40\%-ного раствора пенополистирола, при уменьшении или увеличении концентрации раствора разупрочняющее воздействие снижается.

Использование раствора перополистирола в качестве связующего для приготовления стержневых смесей позволяет уменьшить расходы жидкого стекла и лигносульфоната на $35 \ldots 50 \%$ и позволяет повторно использовать $60 \ldots 80 \%$ отработанной смеси.

\section{ЛИТЕРАТУРА}

1. Дмитриев, Э. А. Исследование свойств стержневых смесей с использованием полимерной добавки / Э. А. Дмитриев, В. В. Петров, Н. В. Захарова // Проблемы механики сплошных сред и смежные вопросы технологии машиностроения: сб. докладов третьей конференции, ВладивостокКомсомольск-на-Амуре, сентябрь 2004 г. - Комсомольск-на-Амуре: ИМиМ ДВОРАН, 2005. - С. 189.

2. Исследование влияния полимерной добавки на свойства стержней на основе ЛСТ / А. И. Евстигнеев, Н. В. Захарова, В. В. Петров, Э. А. Дмитриев, Е. А. Тютина // Литейное производство. - 2006. - № 1. - С. 5-7.

3. Захарова, Н. В. Разработка комбинированных связующих композиций на основе полимеров / Н. В. Захарова // Повышение эффективности и инвестиционной и инновационной деятельности в Дальневосточном регионе и странах АТР: материалы междунар. науч.-практ. конф., Комсомольск-наАмуре, 3-4 октября 2005 г. Ч. 3 / редкол.: Ю. Г. Кабалдин (отв. ред.) и др. - Комсомольск-на-Амуре: ГОУВПО «КнАГТУ», 2005. - С. 144.

4. Пат. 2288804 РФ МПК В22С 1/16 Смесь для изготовления литейных стержней / В. И. Якимов, В. В. Петров, Э. А. Дмитриев, Н. В. Захарова; заявитель и патентообладатель Открытое акционерное общество «Комсомольское-на-Амуре авиационное производственное объединение имени Ю. А. Гагарина». - № 2004137561/02; заявл. 22.12.2004; опубл. 10.12.2006. Бюл. № 20.

5. Петров, В. В. Стержневая смесь с использованием полистирола в качестве связующего раствора / В. В. Петров, Э. А. Дмитриев, Н. В. Захарова // Литейное производство. - 2006. - № 7. - С. 17-18.

6. Петров, В. В. Химическая активация наполнителя стержневой смеси и исследование физикомеханических свойств смеси / В. В. Петров, Э. А. Дмитриев, Н. В. Захарова // Литейное производство. 2005. - № 12. - С. 5-7.

7. Петров, В. В. Химическая активация наполнителя стержневых смесей и исследование физикомеханических свойств стержней / В. В. Петров, Э. А. Дмитриев, Н. В. Захарова // Литейное производство. - 2006. - № 2. - С. 7-8.

8. Модифицированные полимерно-жидкостекольные связующие для легковыбиваемых форм и стержней / В. В. Петров, Э. А. Дмитриев, Н. В. Захарова, Е. А. Тютина // Проблемы сплошных сред и смежные вопросы технологии машиностроения: сб. докладов третьей конф., Владивосток-Комсомольск-на-Амуре, сентябрь 2004 г. - Комсомольск-на-Амуре: ИМиМ ДВО РАН, 2005. - С. 189-191. 